学術論文

\title{
体内埋込型駆動装置を目指した防水型モジュールロボットユニットの開発
}

\section{Development of Waterproof Module Robot Units for a Future Implantable Actuation Device.}

\author{
松下 光次郎 ${ }^{* 1}$ (正員)，佐々木 実"1 (正員)
}

\author{
Kojiro MATSUSHITA (Mem.), Minoru SASAKI (Mem.)
}

\begin{abstract}
We developed the first prototype module robot units for a future implantable actuation device. It consists of a smart servo motor, wireless power supplies, wireless data communication devices, magnet-coupling actuation system, a waterproof case, and realized compact design: $78 \mathrm{~mm} * 64 \mathrm{~mm} * 52 \mathrm{~mm}, 200 \mathrm{~g}$. We conducted performance-investigation and proved the waterproof property, maximum torque output $0.13 \mathrm{Nm}$, battery use $220 \mathrm{mins}$.
\end{abstract}

Keywords: module robot, implant device, prosthetic device, wireless power supply, magnet coupling.

(2016 年 11 月 24 日受付, 2017 年 4 月 25 日再受付)

\section{1 緒言}

近年，医療福祉機器の発展と共に，体内に機器を配 置して診療・治療に役立てる体内埋め込み型技術も発 展している，これまでに，不整脈の調律異常を改善す るために心臓へと電気刺激を与えるペースメーカー [1]や，パーキンソン病患者の非運動障害を抑制するた めに脳へ電気刺激を与える DBS (Deep Brain Stimulation) 装置[2], 心臓の機能を代替する人工心臓 [3]などが実用化し既に普及している，そのような状況 の中で, 我々は先行研究において, 医療ブレイン・マ シン・インターフェース(BMI)の実現を最終目標とし, 脳表面に配置した電極により計測される皮質脳波のた めの体内埋込型脳波計測装置[4]の開発や，皮質脳波に よりリアルタイムに操作可能なロボットアーム制御シ ステムの研究[5]など, 将来を見据えた新規的な体内埋 め込み技術の研究開発を進めてきた。

そこで次の段階として，ロボットアームなど駆動部 の体内埋込化技術に着目した。これまでの生体信号に より制御される電動義手[6]は, 装着するソケット部に 駆動部およびその制御器が内蔵されている構成である が長期使用を前提とするシステム設計になっていると は言いがたく, 配線の問題など利便性に大きく影響し ていた. また先行研究において, ロボットハンドを本 物の手に見せることや防水性の向上を目的として手の

連絡先：松下 光次郎, $\bar{\top}$ 501-1193 岐阜県岐阜市柳戸 1-1, 岐阜大学工学部機械工学科, kojirom@gifu-u.ac.jp ${ }^{* 1}$ 岐阜大学
皮膚を模倣したゴム製カバーを被せるなど試みる場合 [7]もあるが，関節動作部より磨耗し破けやすいという 問題が生じることとなる，そのような問題点を解決す るため, 体内埋込を前提条件とした密封・防水型ワイ ヤレス・モータ制御器と, エフェクタ部を着脱式動作 モジュールとする装置の実現を目指す。その中で本論 文は，第一段階として，先行研究で蓄積した体内埋め 込み技術（ワイヤレスデータ通信，ワイヤレス給電） に非接触で動力伝達を可能とするマグネットカップリ ング技術[8]を組み合わせたモジュールロボットユニ ットを開発し，その性能検証結果を報告する。 なお現 段階では，体内埋め込みのサイズは考慮せず，装置密 封時における通信・給電・動力伝達の基本性能評価を 主眼としている。

\section{2 提案システム}

提案するモジュールロボットユニットの構成要素 は，Fig.1(a)に示すように，(1)3D プリンタ製造・ABS 樹脂製ケース，(2)サーボモータ，(3)ワイヤレスデータ 通信回路，(4)バッテリ管理回路，(5)リチウムポリマー 電池, (6)ワイヤレス充電回路 (受電器), (7)フェライト シート，8バッテリ電圧計測用端子，99イヤレス給 電回路（送電器）で構成される。 またモジュールロボ ットユニット 1 個の組立は, Fig.1(b)に示すように, 構 成要素(2)〜8を樹脂ケースに入れ，樹脂溶着にて封止 することで完成する.サイズは $78 \mathrm{~mm} * 64 \mathrm{~mm} * 52 \mathrm{~mm}$ で, 重さは $220 \mathrm{~g}$ となる. 溶着封止したことで密封性・防水 性を確保，ワイヤレスデータ通信（Bluetooth）による 


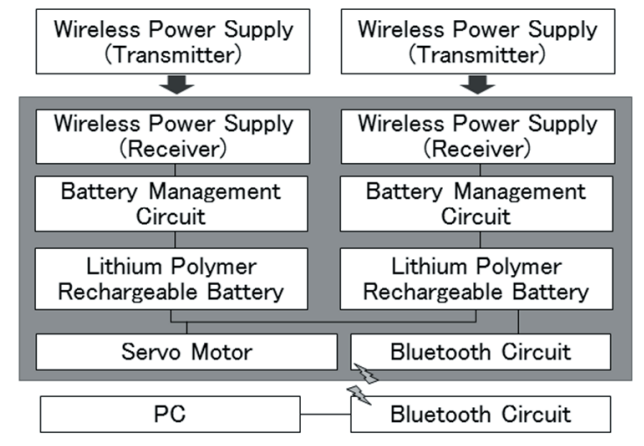

(a) System architecture

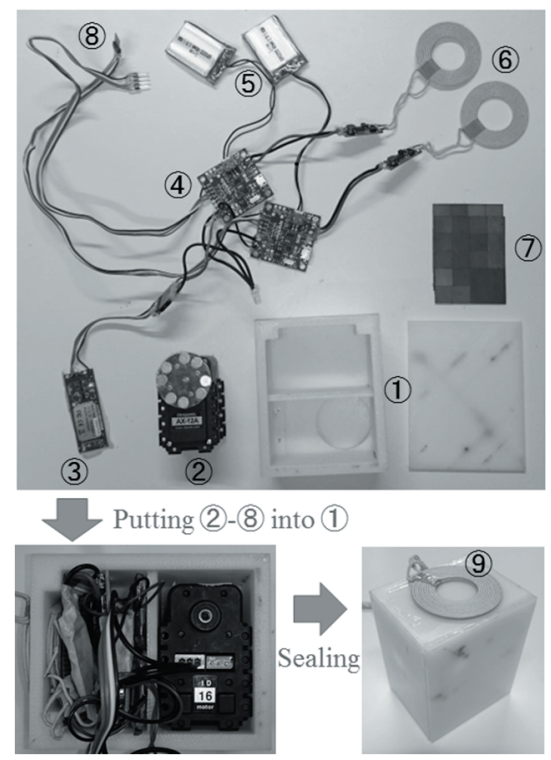

(b) Assemble process

Fig. 1 Proposed module robot unit.

モータ制御, マグネットカップリングによる動力伝達, ワイヤレス給電による遠隔充電を実現している．本節 では，特に主要機能である「ワイヤレス・モータ制御 システム」「ワイヤレス給電システム」「マグネットカ ップリング駆動システム」について以下に述べる.

\section{1 ワイヤレス・モータ制御システム}

提案システムで用いたサーボモータは Robotis 社製 スマートモータ Dynamixel AX-12 である. シリアル通 信によるモータ制御が可能となっていることから， Sparkfun 社製ワイヤレス通信回路 Bluetooth Mate を接 続し, PC から直接的に Bluetooth 通信制御 (通信方式: 非同期シリアル通信 19200bps）を実現している.なお, Dynamixel AX-12 の特徵の一つは制御コマンドにより， 角度制御 (0〜270 度範囲) だけでなく, 角速度制御 (無 限回転）が可能となっている.

\section{2 マグネットカップリング駆動システム}

マグネットカップリング駆動システムは, ネオジム 磁石（直径 $6 \mathrm{~mm}$ ・厚さ $2.5 \mathrm{~mm}$ ・磁束密度 $220 \mathrm{mT}$ ） 8 個 を回転軸に設置したモータ Dynamixel AX-12 と，ネオ ジム磁石 8 個を内蔵したロボットアーム／車輪部品で 構成される. マグネットカップリング・モータ側の磁 石は, Fig.2 に示されているように, $\mathrm{N}$ 極と $\mathrm{S}$ 極の面が 交互に合計 8 個配置となる．また，マグネットカップ リング・ロボット部品（ロボットアーム・車輪）の磁 石は, Fig.3 に示されているように，モータ側磁石と N/S が対になるように配置されている. これにより口 ボット部品がモータ軸に対して定位置で固定され，モ 一タの回転トルクを伝達することが可能となっている. なお，マグネットカップリング距離は $1.5 \mathrm{~mm}$ である

(Fig.4 のケースデザイン内モータ領域部に示されて いる肉厚 $1.5 \mathrm{~mm}$ の箇所).
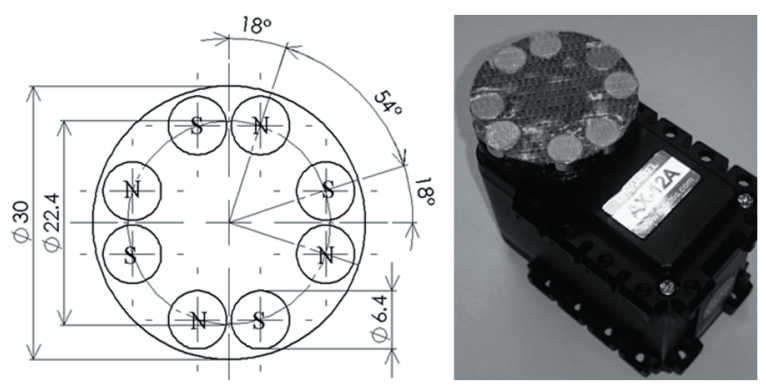

Fig. 2 Magnet-coupling system (motor).

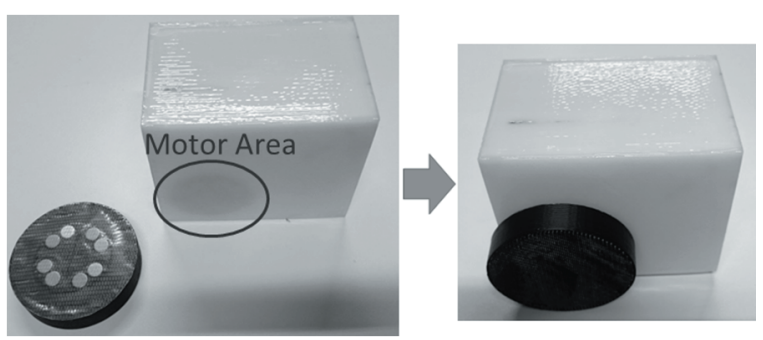

(a) The wheel part with magnet-coupling.

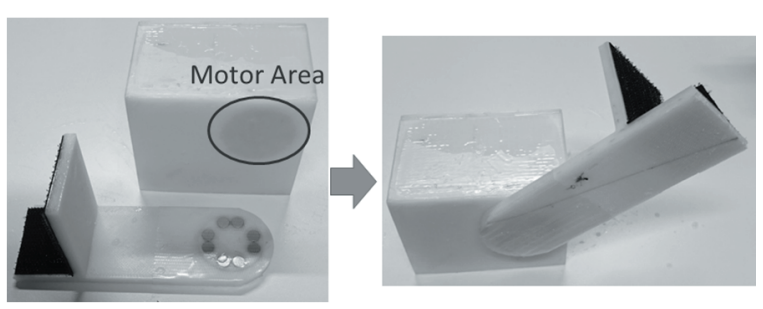

(b) The arm part with magnet-coupling.

Fig. 3 Robot components for module robot units. 


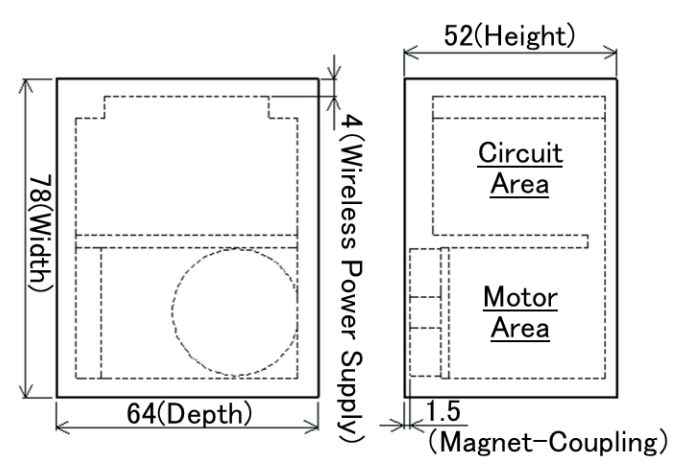

Fig. 4 The case design of a module robot unit.

\section{3 ワイヤレス給電システム}

ワイヤレス給電システムは, Seeed Studio 社製ワイヤ レス充電モジュール SKU106990017, SparkFun 社製バ ッテリ管理回路 Battery Babysitter, リチウムポリマー充 電池 $3.7 \mathrm{~V} 400 \mathrm{~mA}$ で構成される.また今回使用するモー 夕 Dynamixel AX-12 の駆動電圧は 7V 以上であるため, 充電池 2 個を直列接続し使用する必要があるため, ワ イヤレス充電モジュールとバッテリ管理回路を各 2 個 使用している.

ワイヤレス充電モジュール 1 個の送電性能は給電範 囲 2～10mm であるので，ケースの厚み（Fig.4の回路 領域側面）が $4 \mathrm{~mm}$ 厚であることから許容範囲内であ ることがわかる.また, 給電能力も $5 \mathrm{~V} 1 \mathrm{~A}$ と高い上に フェライトシートによる磁気防御もしており, 充電中 の無線通信およびモータ制御も可能である.

\section{3 性能検証}

モジュールロボットユニットの性能検証として, 遠 隔に動力を伝達するマグネットカップリング駆動，ワ イヤレスデータ通信によるモータ制御, ワイヤレス給 電の 3 種類の実験を行った.

3.1 マグネットカップリング駆動システム

モータ・トルクを伝達するマグネットカップリング の性能を検証するため, レプトリノ社製 6 軸力覚セン サ CFS034CA301U（計測可能範囲 : Fz: $\pm 300 N$, FxFy : $\pm 150 \mathrm{~N}, \mathrm{MxMyMz}: \pm 4 \mathrm{Nm})$ を使用し実験を行った. 実験装置を Fig.5 に示す. マグネットカップリング・ ロボット部品 (車輪) 側に 6 軸力覚センサを固定し,
$\mathrm{X}$ 軸方向， $\mathrm{Z}$ 軸方向， $\mathrm{Z}$ 軸回転方向に各 5 回負荷をか け，マグネットカップリングの許容範囲を計測した。

実験結果を Fig.6 に示す. Fig6(a)より回転トルクが $0.134 \mathrm{Nm}$ まで出力可能であることを確認できる.この 数值は, 内蔵するサーボモータ Dynamixel AX-12 の最 大トルク $1.5 \mathrm{Nm}$ の 1/10 で有ることから, より強力な ネオジム磁石を使用することで更なる高性能化が可能 といえる.また, Z 軸方向の耐久力は約 9.5N (Fig.6(b)), Z 軸方向の耐久力は約 9.3N(Fig.6(c)) と確認でき, 約 $8 \mathrm{~kg}$ までの負荷に対し車輪/アームの固定が可能といえる.

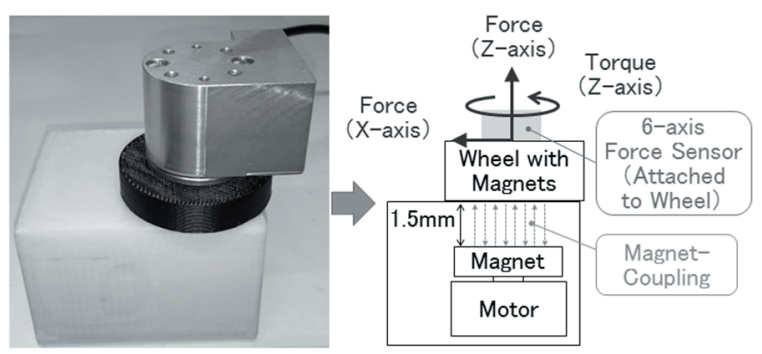

Fig. 5 Experimental setup for evaluating magnet -coupling system.

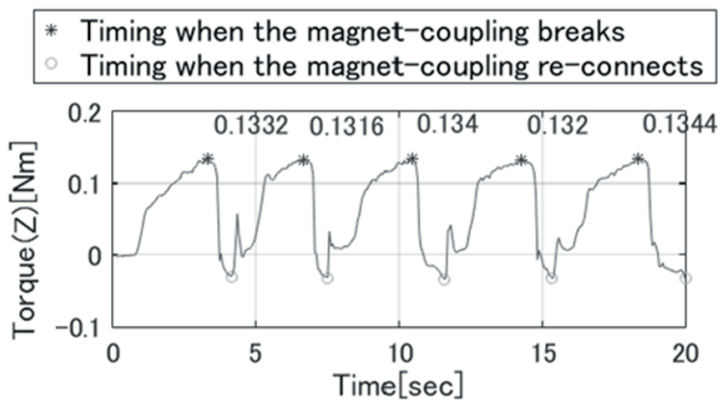

(a)

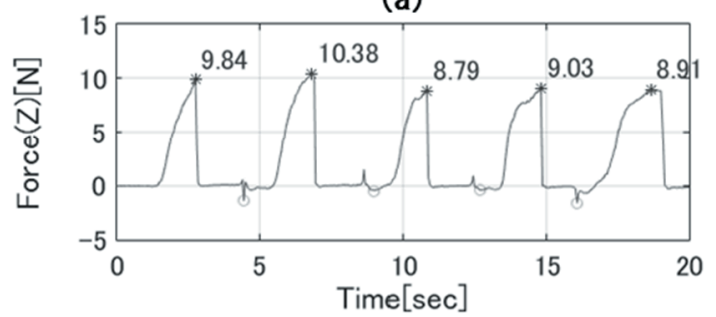

(b)

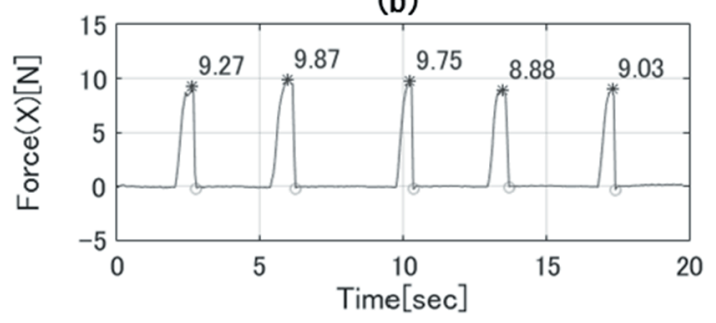

(c)

Fig. 6 Force and torque delivered with magnet -coupling system corresponding to Fig5.

(a) Z-axis Torque, (b) Z-axis Force, (c) X-axis Force. 


\section{2 ワイヤレスデータ通信によるモータ制御}

ワイヤレスデータ通信とモータ駆動時の安定性・持 続性の検証のため, モジュールロボットユニットに対 し制御 PC より 1 秒ごとに制御コマンド（10 バイト） を Bluetooth 送信し，モータ 90 度回転動作を繰り返え させ, 満充電の状態から機能停止までの電圧変化を計 測する実験を行った. なお計測対象のリチウムポリマ 一電池は 2 個の内のモータ・ワイヤレスデータ通信回 路の両方を接続する電力消費量が高い方を選定した.

Fig.7 に充電池電圧推移図を示す. 結果から, ワイヤ レス通信とモータ駆動を併用して 210 分間連続使用が 可能であることを確認した。 日常生活では装置は断続 使用（電力消費はワイヤレス通信の用頻度 ・モータ負 荷に応じて変動）となることから，電動義手の目安の 運用時間である 4 時間 (半日) に対しても, 使用状態 210 分間, 待機状態 30 分間で対応可能と予想する.

\section{3 ワイヤレス給電システム}

ワイヤレス給電システムの性能検証は, 給電時におけ るバッテリ電圧の推移, および, モジュールロボット ユニット表面の温度状態である。

\section{(i) バッテリ電圧の推移}

実験は, 3.2 節の実験後の機能停止状態からワイヤレ ス給電を実行し, 満充電までの充電池の電圧を計測し た。なお前節と同様のリチウムポリマー電池

（3.7V400mAh）1個を対象とした. 結果として, Fig.8 に示されるように，満充電までに要する時間は約 130 分ということが判明した。

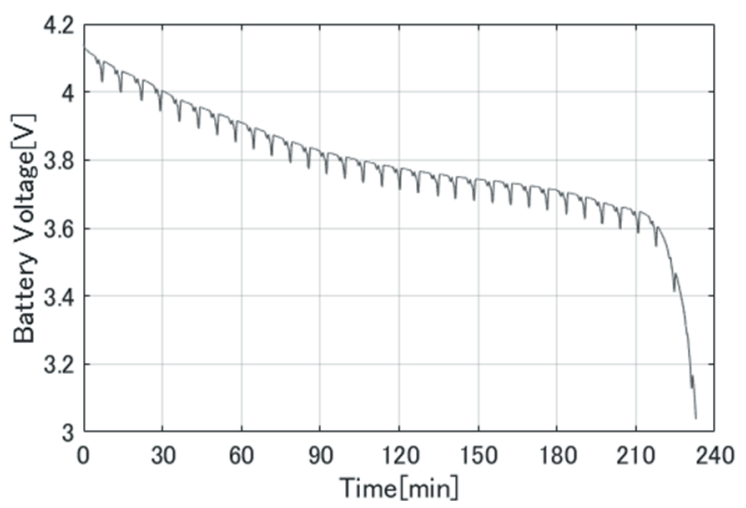

Fig. 7 Transition on battery voltage during wireless data communication and motor actuation. (ii) 表面温度分布

本研究は体内埋込を最終目標としていることから， 給電時における最も高い温度が体内で火傷を生じない ことを確認することが重要となる(温度の生体適合性)。 そこで，給電時のモジュールロボットユニット表面の 温度分布を FLIR 社製サ一モグラフィ i7 にて計測した

Fig.9 に結果を示す。表面温度は最大 39 度であり, 長時間，身体に触れていたとしても低温やけどが生じ ないことがわかり，体内留置が可能なシステムと角に した。なお今回のプロトタイプは，比較的高い電力伝 送を行っているため, 将来的にはより低い電力伝送に 変更し，更なる安全性の向上に努める予定である。

\section{4 水中試験}

最後に, 体内に比較的類似する環境条件をとして,

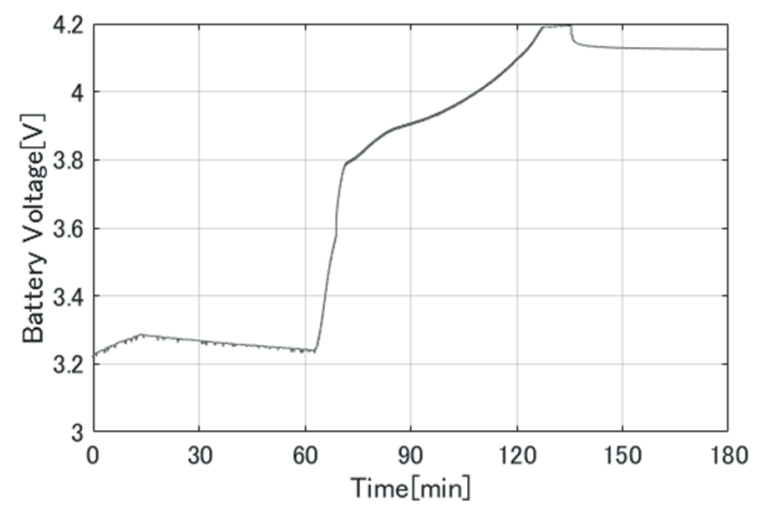

Fig. 8 Transition on battery voltage during wireless power supply.

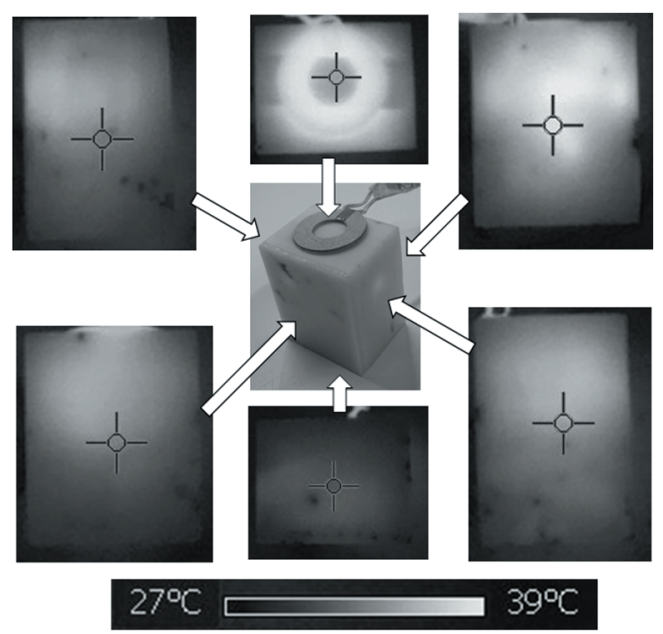

Fig. 9 Temperature condition during wireless power supply. 


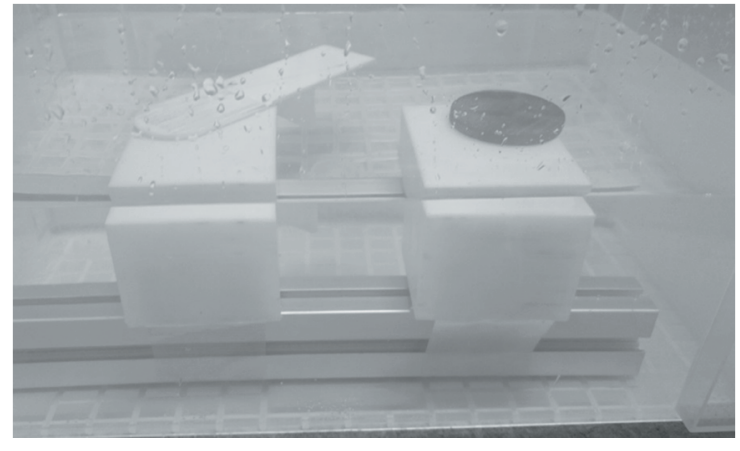

Fig.10 Experimental setup for water proof.

水中 $(360 \mathrm{~mm} * 240 \mathrm{~mm} * 20 \mathrm{~mm})$ における検証実験を行 った.ここでは，主にモジュールロボットユニットの 密封性とワイヤレス通信性能の確認, 体内埋め込夕以 外の用途の可能性の検討を行った.

\section{1 長時間水没実験}

密閉性・防水性を確認するため, ロボットモジュー ルニニットを重りにつけた状態で 1 時間水没させ，そ の後, 空気中においてワイヤレスデータ通信によるモ ータ制御およびワイヤレス給電の動作確認を 5 回繰 り返し行った（Fig.10）. 結果として, 装置の一連使用 プロセス（環境変化および充電も含めた温度変化）に おいても, 不具合無く密閉性・防水性を維持している ことを確認できた.

なお補足として，モジュールロボットユニット全体 を水中に沈めた場合に生じる浮力を 3.1 節と同様の実 験装置を用いて計測した結果, 約 $0.81 \mathrm{~N}$ と判明した.

\section{2 水中ワイヤレスデータ通信実験}

水中にモジュールロボットユニットを配置し， PC とのワイヤレスデータ通信状態の確認を行った。 その 結果として, ワイヤレスデータ通信は可能だがユニッ 卜側面から空気中まで約 40mm の距離を確保する必要 があると判明した (通信成立条件)。すなわち, ユニッ トが 40mm 以上水で覆われる場合には通信が不可能と なる。また，ユニットを水中に入れる瞬間も， PC 側 Bluetooth 装置とのペアリングが一旦遮断することが わかった.このような通信不能となる理由は, Bluetooth が $2.4 \mathrm{GHz}$ 帯であることから, 電波が水に吸収される ことに起因する.ただし, 体内埋込装置は通常皮膚直 下の留置を前提としていること, また, 皮膚直下にお
いて物理的に通信を遮断するものは脂肪（水と同様の 遮断性と仮定）となるが，全方位 $40 \mathrm{~mm}$ 厚覆われるこ とも考えにくいため, 体内埋め込み時のデータ通信に は問題はないと考える.

\section{3 水中口ボットとしての活用例}

提案するモジュールロボットュニットは, 本来, 体 内埋込型駆動機器を目指し開発を行っているが，その 密封性を活かし, 水中ロボットへの技術展開も期待で きる.本節ではそれらデモ・ロボットを示し考察する.

(i) 提案の水中ロボット

提案するモジュールロボットユニットの転用例と して構築した 2 種類の水中ロボットを Fig. 11 に示す. (a)は 2 自由度ロボットアーム, (b)は二輪ロボットであ る.これらのデモンストレーション結果として, ロボ ットを水中に配置する場合には水の抵抗や浮力が生じ るため, 空気中とは異なるダイナミクスが存在するこ とが分かった，すなわち，マグネットカップリングに よる動力伝達損失が多少あったとしても, 水中におけ る身体と環境の相互作用ダイナミクスを有効利用する ことで，空気中よりも効率の良くタスクを実現できる 可能性があると考える. なお, この相互ダイナミクス の有効利用の概念は, 坂道において身体構造が重力を 有効活用することでモータ駆動力無しに歩行を実現す る受動歩行機[9]の知見に基づくものである. 特に, こ れまでの水中ロボットの研究は潜水艦タイプ以外には 水中マニピュレータ $[10]$ の研究が主であり, ロボット アーム構造における流体ダイナミクスの関係性の検証 に限られてきた. そのため今後, 提案するモジュール ロボットユニットを用いて, ロボットアーム以外の多 種多様な多自由度構造と水中環境ダイナミクスの相互 作用の検証が, 興味深い研究課題になると考えている. (ii) 考察

近年, 生活支援ロボットの普及が望まれているが, 安全性も確保する必要がある[11,12]. そのため, 水道 周りおよび風呂回りは水による感電の危険性があり, 積極的な支援口ボット開発には至っていない，それに 対し, 提案する防水型モジュールロボットユニットは, データ通信・給電・動力伝達を装置内外にて空間的に 分離していることから電気漏れを起こすことがないた め, 水周りの支援システムの構築に大きく貢献すると 考えている.

また，近年注目されるインフラ検査ロボット[13]に 


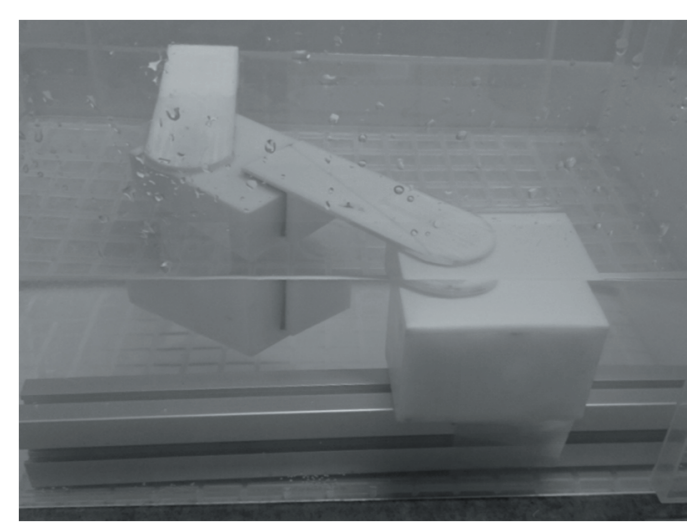

(a) 2-DoF robot arm

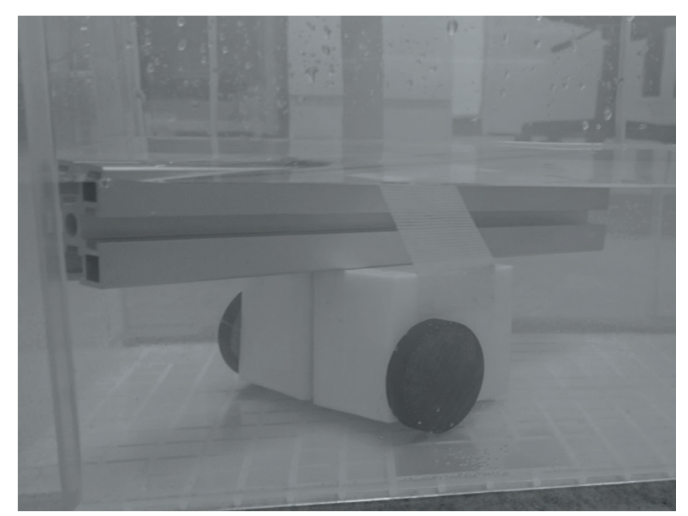

(b) 2-wheel mobile robot

Fig. 11 Demonstration with module robot units.

も活用できると考える．ニーズの一つに人が入ること が出来ない狭い空間での水路検査・水路清掃の実現が あるが，そのような環境においてロボットを運用する ためには単に防水性能を確保するだけでなく，モータ 軸などの駆動構造に絡まり，動作を停止させる恐れの ある藻やゴミに対する対策も必要となる。すなわち, 藻やゴミが絡まない構造設計を行うか, もしくは，そ れらが簡単に取り除けるようなメンテナンス性が望ま れる. 本提案装置は, 動力伝達をマグネットカップリ ングで行っているため, アーム軸／車輪軸の取り外し が用意であるため，これら条件に適合すると考える。

\section{5 結言}

本研究は, 体内埋め込み型モータ駆動装置を最終目 標とした密閉型モジュールロボットユニットの第一プ ロトタイプの開発報告である。提案装置はサイズ $78 \mathrm{~mm} * 64 \mathrm{~mm} * 52 \mathrm{~m}$ ・重量 $220 \mathrm{~g}$ にて, ワイヤレスデータ 通信 (約 210 分間連続使用) ・ワイヤレス電力伝送 (満 充電まで約 130 分間)・マグネットカップリング動力伝 達（トルク $0.13 \mathrm{Nm}$ ）の機能を実現した. 更には，体
内と仮定した水中動作検証を行い，日常生活用途に耐 え得る体内埋め込夕型駆動装置の実現の可能性を確認 した.

\section{謝辞}

本研究は，JSPS 科研費 JP 25702035，および，テニ ユアトラック普及・定着事業の助成を受けたものです.

\section{参考文献}

[1] B. Larsson, H. Elmqvist, L. Ryden, H. Schuller, Lessons from the first patient with an implanted pacemaker: 1958-2001, Pacing and Clinical Electrophysiology, 26(1 Pt 1)pp.114-124, 2003.

[2] 深谷親, 片山容一,脳深部刺激療法によるパーキンソン病 の治療, 医科器械学 73(7), pp.347-352, 2003.

[3] OH. Frazier, RD. Dowling, LA. Jr Gray, NA. Shah, T. Pool, I. Gregoric, The Total Artificial Heart: Where We stand. Cardiology, Vol.101, No.1-3, pp.1507-1514, 2004.

[4] K. Matsushita, M. Hirata, T. Suzuki, H. Ando, Y. Ota, F. Sato, S. Morris, T. Yoshida, H. Matsuki, T. Yoshimine, Development of an implantable wireless ECoG $128 \mathrm{ch}$ recording device for clinical brain machine interface, 35th Annual International Conference of the IEEE Engineering in Medicine and Biology Society (EMBC2013), pp.1867-1870, 2013.

[5] T. Yanagisawa, M. Hirata, Y. Saitoh, H. Kishima, K. Matsushita, T. Goto, R. Fukuma, H. Yokoi, Y. Kamitani, T. Yoshimine, Electrocorticographic control of a prosthetic arm in paralyzed patients, Annals of Neurology, vol.71(3), pp.353-361, 2012.

[6] 横井浩史, 矢吹佳子, 關達也, 中村達弘, 森下壮一郎, 加藤龍，高木岳彦，高山真一郎，筋電制御型の義手，バ イオメカニズム学会誌 38(1), pp.39-46, 2014.

[7] 粕谷昌宏, 加藤龍, 高木岳彦, 伊藤寿美夫, 高山真一郎, 横井浩史，身体を拡張する筋電義手 : "障害"を再定義す るテクノロジーの実現を目指して，情報管理，Vol.58， No.12 pp.887-899, 2015.

[8] 植田尚也, 相良慎一, 武村史朗, ネオジム磁石によるマ グネットカップリングを用いた水中マニピュレータ用関 節の試作，ロボティクス・メカトロニクス講演会講演概 要集, 2A2-F09, 2012.

[9] S. Collins, A. Ruina, R. Tedrake, M. Wisse, Efficient bipedal robots based on passive-dynamic walkers, Science, 307(5712), pp.1082-1085, 2005.

[10] 竹内永, 原文雄, 水中ロボットアームの流体付加トルク の低減の研究, 日本機械学會論文集 C 編, 63(611), pp.2377-2384, 1997.

[11］木村哲也，大賀公二，生活支援ロボット安全規格 ISO13482 とシステム安全, 日本信頼性学会誌：信頼性 37(2), pp.61-65, 2015.

[12] 岡本球夫, 久米洋平, 生活支援ロボットの安全に向けた 取り組みと ISO13482 認証, 日本信頼性学会誌: 信頼性 37(2), pp.66-70, 2015.

[13］新田恭士，国土交通省における ICT, 次世代社会インフ ラ用ロボットの導入推進の取組について, 計測と制御, Vol.55, No.6 pp.470-476, 2016. 